\title{
The Use of Color Imagery in the Novels of Toni Morrison
}

\author{
By Saumitra Chakravarty*
}

\begin{abstract}
This paper attempts to show how Toni Morrison uses color as an image and a symbol in her novels to "un-matter" the race-sex combine which relegates the women of color to the very bottom of the social ladder and causes the Black woman writer to be ignored and derided as a voice of complaint exploiting race and gender to propagate her writing. In her novels, color moves beyond the reductivist black-white binary to achieve a mythical African significance of its own, countering the cruel reality of life in America. The use of an alternative mythography inherent in African racial memories also counters the power of the 'logos' interpreted as the written word by a dominant culture against the assumed inferiority of orality. Color is inherent in the traditional activities that Black women pursue, perhaps nowhere better than in the patchwork quilts they sew, a predominant image of the stories these women tell. It is also latent in the horror of their individual and racial memories of slavery and exploitation. This paper attempts to demonstrate that in Morrison's work color is used to objectify both suffering and salvation. The horrors of slavery being expressed through color imagery may be a way to heal the trauma and perhaps lay it to rest. 'Black' loses its negative connotations and assumes various shades of 'black-ness' indicating various degrees of integration into the African identity. By using color as an alternative signifier in her novels, though not as an aggressive power dynamic, Morrison is thus offering a more comprehensive vision.
\end{abstract}

Keywords: Color, Signifier, Black-White, Power-Dynamics, Myth-Making

The interchangeability of the 'logos' with the 'mythos' acquires strong overtones in Black literature. For the Black writer, particularly the woman writer, who is defined by color and sex, the search is not only for a strong individual, racial and gender identity, but for the establishment of a system that exists in contradistinction to the normative one, which is traditionally white and male. Barbara Smith in her essay, Toward a Black Feminist Criticism, writes: "Black women's existence, experience, and culture and the brutally complex systems of oppression which shape these are in the "real world" of white and/or male consciousness beneath consideration, invisible, unknown." (Smith, 1992, p.168) To build up an identity under such circumstances is to establish an alternative dynamic of strength either through the establishment of the lesbian relationships (in terms of the strong female bonding overriding heterosexual ones) Smith describes through the example of Toni Morrison's Sula, or by rendering the color-binary ineffective so that the race-sex combine is denuded of its power, at least within the victim's consciousness. The power of the 'logos', in this case the written word, has always belonged to the racially and sexually superior which has purposefully built up an entire structure of

*Professor, National College, Bangalore, India. 
myths to substantiate that superiority against the assumed inferiority of orality. It will be the purpose of this paper to show how the use of an alternative mythography also based on color as a signifier and on the use of different colors inherent within the reductivist black-white binary, helps to propagate a new perspective, or in the case of the Black woman, to reverse this social and cultural stratification as indicated in the novels of Toni Morrison.

In Playing in the Dark, Morrison says: "Black slavery enriched the country's possibilities. For in that construction of blackness and enslavement could be found not only the not-free but also, with the dramatic polarity created by skin color, the projection of the not-me." (Morrison, 1993, p.38). The white has a history, the black only mythology, the white the power of the written word, the black only orality, the white's rationality, logic, judgement is as opposed to blind belief, superstition, nostalgia for a mythical African past. History has not only looked at the Negro through the eyes of the white man, but taught the Black to look at himself through the same myopic prism. W.E.B. Du Bois in The Souls of Black Folk says: "one even feels his two-ness-an American, a Negro; two souls, two thoughts, two unreconciled strivings; two warring ideals in one dark body..." (quoted in Sanders, 2005, p.42). By assuming the nomenclature 'African-American' and translating it almost literally into their daily lives, the Black, particularly the women in Morrison's novels, have sought to revive an African past and to view their own predicament in a racially divided society as part of a collective memory of a Black sisterhood of suffering. Toni Morrison has shown how the semiotics of color embedded within the black-white binary can be used to demolish an entire superstructure of myths upon which the white man has built his dominator status as earlier indicated in this essay. By "eliminating the potency of racist constructs in language", she can achieve what in her essay Home she calls "unmatter race" (Morrison, 1998, pp.3-4) and bring this down from an impossible Utopian yearning to a doable modern activity. One way of doing this is by changing these color codes as signifiers thus stripping them of the arbitrariness of the significance attached to them and reversing the ratio of psychological power that the white traditionally enjoys. In so doing, she not only attempts to retrieve the Black racial identity but also to establish an alternative dynamic that helps to assuage the collective and individual memories of exploitation.

In Morrison, color is used to objectify both suffering and healing. To be able to talk about the horror of slavery imagistically through color helps to objectify it within the victim's mind and perhaps, lay it to rest. Also, changing the existing connotations of a particular color as a power signifier in an alien and hostile environment, helps to negate one's slave status, particularly in the context of the vibrant myth-making tradition which is so much a part of the African racial identity. Nancy Kang in her essay To Love and be Loved, talks of "the endemic nature of slavery in the black consciousness, how its traumas and degradations surface in language(s) and act(s), and how the struggle against self-estrangement demands an understanding of how our representations shape us and how we shape our representations" (Kang, 1998, 
p.44). The use of color is particularly relevant in such a representation because color is inherent everywhere in Black women's lives and their ethnic African identity; in their memories of the wild and the forest, in the stories they tell through generations of female bonding, in the brightly colored patchwork quilts they stitch, in the fruit and vegetable preserves they bottle, in the plant medicines the medicine women prepare as seen both in Morrison's Song of Solomon and Gloria Naylor's Mama Day. The questions that this essay will attempt to answer are: is it possible for the Black woman to free herself not only from the power of 'whiteness' and all the hegemony ritually associated with it, but also from the inverted power structure of being the martyr, the victim, from hatred and fear and the power of what she calls 're-memory' which re-visits suffering and makes the individual suffering part of the collective memory of African women? Can the colors 'black' and 'red' be stripped off their horrifying connotations in the slave past and even the comparatively moderate present within the black consciousness? Within the black-white binary she associates a range of colors not only with racial superiority or inferiority but the social, economic and cultural privileges--or lack thereof-- associated with it. Are forgiveness and peace of mind even possible? There are therefore the 'neutral' colors like green, yellow, blue which are able to surmount racial conflict and bring peace to the Black consciousness at war with itself. As she says in her essay Home: "Counterracism was never an option." (Morrison, 1998, p.4)

The answer is to revitalize 'blackness' with the vibrancy of its past in its African roots in contrast to its humiliating connotations in its diasporic context. It is important to know who you really are if you want to counter what other people think of you. Therefore racial purity undoubtedly holds great significance in Toni Morrison's work. In her essay, 'African-American Women's History: The Metalanguage of Race', Evelyn Brooks Higginbotham states: "For blacks, race signified cultural identity and heritage, not biological inferiority [....] specifically race as the sign of perceived kinship between blacks in Africa and throughout the diaspora." (Higginbotham, 1996, p.197) To that extent 'black' is an entire spectrum rather than a single color in Morrison and its various shades indicate varying degrees of integration into the African racial identity in the divisive American context. In Song of Solomon, Pilate tells Milkman and Guitar: "You think dark is just one color, but it ain't. There're five or six kinds of black. Some silky, some woolly. Some just empty. Some like fingers. And it don't stay still. It moves and changes from one kind of black to another. Saying something is pitch-black is like saying something is green...Well night black is the same way. Might as well be a rainbow." (Morrison, 1989, pp.40-41) The wild Pilate herself has "inky, berry-black lips" (ibid., p.317) which are "wine-stained, blueberry dyed" (ibid., p.30). In Beloved, Paul D. is a "hazel-nut man" with "peachstone" skin. (Morrison, 1991, pp.9, 14) In Tar Baby, 'tar' may also be taken as the essence of blackness; the color of the woman in the canary-yellow dress holding up three eggs, of Son with his whip-lash, chain-gang hair, of the island women, of the blind riders in the hills and the swamp women; the blend of the mythical and 
the real which is so much a part of the African consciousness and which Morrison weaves into her texts. In an earlier essay on The Feminine Divine in the works of Toni Morrison and Mahasweta Devi, I have noted that Morrison's images of the communitarian female who builds bridges across cultures is shown through three types of women. "First, there are those representing an ancient mythical past. This is the eternal female, Africa/Goddess/Matriarch with pronounced breasts and hips like Therese of the magic breasts, the water goddess and the swamp women, the black woman in the canary yellow dress holding up the eggs in Tar Baby, Circe in Song of Solomon, Connie the Black Madonna in Paradise. Then there are the homemakers who deliberately pursue the ancient traditions of their mothers and grandmothers to perfection in an effort to gain re-possession of their own lives. Finally there are the androgynous figures of Pilate in Song of Solomon, Baby Suggs in Beloved, Eva Peace in Sula, who like Shug Avery in Alice Walker's The Color Purple, are strong women and natural healers." (Chakravarty, 2007, pp.138-139) They are independent of 'maleness' but love it for its own sake. They establish themselves firmly in the tradition of African matrilinear and matrifocal dynasties celebrated in African legends and oral histories like those of the 'magajiya' or Queen Mother in Nigeria and the Queen of Sheba.

It is a blackness which Negroes like Jadine, the fashion model in Tar Baby as well as Sydney and Ondine have betrayed through their imitation of white standards and ways of living. In so doing, they have denied their African past and attempted adoption into the American culture. Pilate's sister-in-law in Song of Solomon who, as the wife of the richest Negro in town, makes no attempt to assimilate into the essential black identity, is a "lemon-yellow woman" and her daughters have "buttery complexions" and hair the color of "wet sand". (Morrison, 1989, pp. 137, 10, 33) In Sula, Nel's mother is "custard-colored" (Morrison, 1993, p.35) and Jadine in Tar Baby has been labelled "yalla" by the local blacks on the island: "Yallas don't come to being black natural-like. They have to choose it and most don't choose it." (Morrison, 1983, p.133) Geraldine, in The Bluest Eye, a mulatto, is "sugar brown" (Morrison, 1999, p.64) who hated any suggestion of wool and therefore of African-ness, in her son's hair. In The Bluest Eye however, Pecola's blackness is an entity, it is the prototype for ugliness rejected alike by black and white. Viewing herself through 'white' eyes just as other blacks do to her, she feels her blackness to be "static and dread" "creating that vacuum edged with distaste in white eyes." (ibid., p.37) So every night without fail, she prays for blue eyes, the white and therefore by definition, the normative pre-requisite for beauty. Black is also the color of the unyielding soil denied the beauty of marigolds in the prelude to the novel, just as it is of Pecola's womb carrying her father's baby. The white yardsticks of beauty are symbolized in the novel by the whiteness of milk in the Shirley Temple cup and in the Mary Jane wrappers of sweets through the consumption of which Pecola tries to internalize the accepted norms of beauty. These norms drive the black child Claudia to murderous fury towards blue-eyed, yellow-haired, pink-skinned dolls. Within this, lies the implicit condemnation of the Black community 
which by its surrender to these white standards, drives one of its own to despair and madness. As Linden Peach, in his book Toni Morrison has pointed out: "In her novels, the struggle to define and create a notion of self that is different from the stereotypical expectations of the larger social and symbolic order inevitably involves a process of inner dislocation for the African-American." (Peach, 2000, p.34) Caught up in this limbo between impossible yearning and a brutal reality, Pecola's 'blackness' is equated with ugliness and lack of grace which leaves a trail of chaos and destruction in its wake; in the splattering of blueberry cobbler in the almost antiseptic whiteness of her mother's kitchen, in the dead black cat with icy blue eyes in Junior's home and the death of the old dog with sea-green-edged eyes in Soaphead's yard; all of which is followed by her miscarriage of her father's baby.

Beyond the historic and present connotations of blackness associated with the word 'nigger' and its relation to slavery, a savage past and an intolerable present in the Black consciousness, lies its horror of the color 'red', particularly in Beloved. Red is the color of the hickory fire that burns Six-o, the slave caught trying to escape, of roasting Negro blood, of the branded flesh on their bodies, of baby blood oozing like oil through Sethe's fingers and of the red ribbon with a little black girl's scalp attached to it that the old Negro Stamp finds. So in Baby Suggs' final surrender to a world of color in her quilt on her bed, Stamp hopes that she stuck to what was harmless in the world, "to blue, yellow, maybe green, and never fixed on red." (Morrison, 1991, p.222) The novel opens with the pool of red and undulating light in Sethe's house which indicates the presence of the murdered baby's ghost. The pale pink headstone that Sethe chooses for her murdered baby's grave may carry undertones of the red of her shed blood, but it also carries the pre-lapsarian innocence of a baby's fingernail and of a dawn prior to the brutal reality of a day in the life of a Negro. Following the red of her baby's blood and the pink of her headstone, Sethe turns as "color-conscious as a hen". (ibid., p.48) All the colourful molly apples and yellow squashes she works with at the restaurant and the flambuoyant dawn colors she leaves for work in, leave her unmoved. Color returns to her life with the arrival of the adult Beloved, in her attempts to dress her up in multi-colored harlequin costumes that are almost an assault against the muted browns and greys of Negro life. Equally the blazing colors of the flowers running riot in Sethe's unkempt garden at the end of the novel are a mute revolt against the orderliness of the neat rows of color in Baby Suggs' vegetable patch, similar to those seen in the Black women's kitchen gardens in Paradise. The tumult of Baby Suggs' blueberry party and the iced melon smash signify an excess and a departure from a severely bounded and peripheralized existence that brings the white man to her door unchecked, a reference that is repeated at the end of the novel in the association between the riot of flowers and the arrival of another white man at Sethe's door.

The color 'red' acquires a vibrancy in The Bluest Eye in Cholly's recollection of eating the red heart of the smashed water melon, the only fond memory of his troubled childhood. In Beloved, Six-o's flame-red tongue that defies the redness of the fire that burns him is as much indicative of his fierce 
pride in his racial identity as his indigo skin. He will live on in his seed planted in the Thirty-mile Woman's womb. In the dreams of the poor white girl Amy Denver, red or carmine velvet becomes symbolical of her hopes of emancipation from servitude. However, red is also the color of the lifeless velvet roses that Macon Dead's daughters make, beating the boredom of wealth, spinsterhood and an overbearing fatherly presence. Scattered in the snow, these red petals announce the birth of the first Negro baby in a white man's hospital at the beginning of Song of Solomon.

The white takes color for granted beyond the black-white binary, just as he does the socio-economic privileges that accompany it. While the sky above the houses of Claudia and Pecola remain permanently suffused with a dull orange glow from the fire of the blast furnace of the steel mills, it gradually changes to a cloudless blue in the white, and therefore affluent part of town along with the change from slag heaps to the greenery of 'Whites only' parks. The Bluest Eye opens with the picture-perfect green and white house with the red door housing the perfect white family, whereas the poor black child narrator's house is old, cold and green and even Junior's house, neat, well-decorated and green and gold though it is, is not spared the angry glow of the orange sky.

Green however is a blessed color in Negro life indicative of spiritual regeneration and peace of mind. Baby Suggs becomes a pulpit-less preacher to her people in the green Clearing in the Woods where she invites them to lay to rest anger and hatred and heal their minds and hearts of the horrors of their slave past. The message that Baby Suggs delivers does not differentiate between the religious and the mundane, the strictly spiritual and the attempt to reconstruct a shattered past through a message of self-renewal in America's fragmented society. In these words of practical wisdom are mingled both the Christian spirit of forgiveness and the African ethnic world view, where there is no divisiveness but a reconciliation of apparent polarities, where the fragmented individual body must come together to fuse with the community. As Philip Page says in Dangerous Freedoms: "In the African world view, there are no clear demarcations between life and death, sacred and secular or spiritual and material. Instead the focus is on the reconciliation of opposites in which the cosmos, as well as every community is a balance force field and in which harmonies, coherence and equilibrium are the highest goals." (Page, 1995, p.11) It is in search of such a harmony that Sethe, overcome by unbearable grief at her husband's madness along with her two daughters, one living and one dead, and Denver, alienated by her mother's relationship with Paul D., seek sanctuary in the green light of the Woods. In the Bluest Eye, in the young Pauline's consciousness, the streaks of green of the june-bugs in the trees at night together with the memory of the yellowish color of the lemonade her mother made for her and the purple of the squashed berries that stained her dress are associated with the precious memory of her first meeting with Cholly Breedlove. In the cold grey light of a winter dawn in later life the memory of the green june-bugs is a secret nostalgia she can occasionally indulge in. The blue in the title however is the color of Pecola's dreams represented by the Shirley Temple and Mary Jane images as earlier noted in this essay, but it is 
also the color of the blear-dropped blue in the shopkeeper's eyes and the icy blue of the dying cat's. The eyes of Margaret in Tar Baby are defined as blue-if -it's-a-boy-blue which is both an indication of normative superiority of white beauty as the 'Principal Beauty of Maine' and that of a neglected woman's desperate search for attention.

The dying Baby Suggs dreams of color, of blue, yellow and lavender. She rejects the green sanctuary where she invited the Blacks to meet their slave past head-on and lay its intolerable horrors to rest, which if not exactly a partnership paradigm, at least envisaged a world where race can be 'un-mattered'. Her surrender to world-weariness and dreams of color are a realization that the past is never a closed chapter that can be negotiated at will. An alternative power dynamic is however created in Song of Solomon by Guitar Baines with the gold-flecked eyes, who seeks to keep the ratio of suffering even, with the revengeful killing of whites. Gold here, is a symbol of power in black life just as it is in the gold lettering on the frosted door of Macon Dead's office, his search for the hidden gold which alienates him from his sister Pilate. The image of gold and the creation of a Black power dynamic by the uneasy reversal of the centre-periphery equation also reverses the victim-predator relationship and in so doing goes against the African ethnic world view of the reconciliation of opposites. It ironically exploits the white paradigm of divisiveness unnatural to the Black psyche, to retrieve lost identity and social position. Ruth Dead, battered and bruised by her husband, gives in to a secret indulgence of breast-feeding a growing child: "She had the distinct impression that his lips were pulling from her a thread of light. It was as though she were a cauldron issuing spinning gold." (Morrison, 1989, p.13) What she had in her body was not the breast milk of a black woman but the gold threads the miller's daughter drew from her shuttle in the Rumplestilskin fairy tale, a white man's tale that symbolically enacts a black woman's desperate search for liberation.

By representation through color symbolism, Toni Morrison expounds an entire alternative language of culture that takes its meaning from the underlying structure of activities associated with the daily lives of AfricanAmerican women. The power of orality, 'nommo', the African spoken word represents the life force, giving life to the inanimate, the adjectival, to that which can neither be touched nor seen, but only experienced. This form of experience commonly found in ethnic societies cannot be comprehended in the mainstream culture of technological America. As Philip Page puts it in Dangerous Freedoms, through "the magic power of the word, human beings gave life to otherwise dead objects and materials." (Page, 1995, p.11)

Cornel West states in his essay Afterword that the "denial of race in the "color-blind" past or the postmodern present is the intellectual counterpart of the denial of the legacy of white supremacy in our society and world." (West, 1998, p.301) The race-gender combine is even more so, double nonentities in the mainstream literature and language of the multiracial, though not multicultural society of America. Toni Morrison's attempts by her own admission, are to un-sex and un-race language without erecting an aggressive 
alternative power dynamic. As she says in her essay Home: "My effort to manipulate American English was not to take standard English and use vernacular to decorate it, or to add "color" to dialogue. My efforts were to carve away the accretions of deceit, blindness, ignorance, paralysis, and sheer malevolence embedded in raced language so that other kinds of perception were not only available but were inevitable." (Morrison, 1998, p.7)

It has been the purpose of this paper to show how this has been achieved by her employment of a color symbolism, speaking imagistically in the true myth-making tradition of the Negro, establishing a parallel and therefore more comprehensive literary and linguistic tradition as opposed to the exclusivity of the mainstream dominator culture.

\section{References}

Chakravarty, S., 2007. The Feminine Divine in the Works of Toni Morrison and Mahasweta Devi. In: A. Riem Natale, C. Conti, D. Luisa, M. Renata, eds. The Goddess Awakened: Partnership Studies in Literatures, Language and Education. Udine, Italy: Forum Edizioni, pp. 133-146.

Higginbotham, E.B., 1996. African-American Women's History and the Metalanguage of Race. In: J.W. Scott, ed. Feminism and History. New York: Oxford University Press, pp. 183-208.

Kang, N., 1998. To Love and be Loved. In: B.H. Solomon, ed. Critical Essays on Toni Morrison's Beloved. New York: G.K. Hall, pp.38-47.

Morrison, T., 1983. Tar Baby. New York: Signet Books.

Morrison, T., 1989. Song of Solomon. London: Picador.

Morrison, T., 1991. Beloved. New York: Signet Books.

Morrison, T., 1993. Sula. New York: Signet Books.

Morrison, T., 1993. Playing in the Dark. London: Picador.

Morrison, T., 1998. Home. In: W. Lubiano, ed. The House That Race Built. New York: Vintage, pp.3-12.

Morrison, T., 1999. The Bluest Eye. London: Vintage.

Page, P., 1995. Dangerous Freedoms: Fusion and Fragmentation in Toni Morrison's Novels. Jackson, U.S.A.: University Press of Mississippi.

Peach, L., 2000. Toni Morrison. New York: St Martin's Press.

Sanders, M., 2005. American Modernism and the New Negro Renaissance. In: W. Kalaidjian, ed. The Cambridge Companion to American Modernism. Cambridge: Cambridge University Press, pp.129-156.

Smith, B., 1992. Towards a Black Feminist Criticism. In: E. Showalter, ed. The New Feminist Criticisms: Essays on Women, Literature, Theory. London: Virago Press, pp.168- 185.

West, C., 1998. Afterword. In: W. Lubiano, ed. The House That Race Built. New York: Vintage, pp.301-303. 